\title{
Separatisme dalam Perspektif Sejarah
}

\author{
Djoko Suryo
}

Separatism denotes one of the historical phenomenon that emerges since human society know the form of the building of political life community either in the form of the village federation association, the kingdom or modern state from past time up to now. The phenomena of separatism truthfully there was in the era of old kingdom, for instances, the elasiccal Egypt, Mesopotamia, Greek, and Roman Empire, and the kingdom of Indonesia, for examples, Sriwijaya Majapahit, Demak, Pajang and Mataram. ldeology and the spirit of nationalism and the globalization participate in movitating the separatism in Indonesia either positively or negatively. The phenomenon of separatism mentioned above needs to be solved by approaching and political policies and the strongest great desires from indonesian people themselves to resist the unity of nation and state of Indonesia.

M enjelang pergantian millennium kedua yang baru lalu dunia dikejutkan oleh berbagai peristiwa besar menengarai terjadinya perubahan tatanan dunia baru. Salah satu di antaranya ialah peristiwa terpecah-belahnya negara Adikuasa Uni Soviet Rusia menjadi negara-negara merdeka yang baru. Ironisnya, pada masa yang sama juga terjadi peristiwa runtuhnya tembok Berlin (1990) yang sejak lama telah memisahkan Jerman menjadi dua negara, yaitu Jerman Barat dan Jerman Timur, di samping terbentuknya Uni Eropa (1996). Keduanya menggambarkan munculnya fenomena pisah-gabung di negara-negara Eropa pada akhir abad ke 20, yang secara unik juga dipandang sebagai tonggak sejarah berakhirnya Perang Dingin.

Peristiwa pertama menggambarkan fenomena disintegrasi sementara peristiwa kedua dan ketiga melukiskan fenomena integrasi. Fenomena disintegrasi yang terjadi di Uni Soviet Rusia atau Republik Sosialis Federasi Soviet Rusia itu dikatakan mengagetkan karena kejadian itu di luar perkiraan orang pada umumnya. Orang tidak mengira bahwa negeri yang telah terbentuk secara kokoh selama 74 tahun (terbentuk sejak Desember 1922) dapat runtuh secara "mendadak". Umum sependapat bahwa gerakan separatisme atau pemisahan diri dari sejumlah republikrepublik non-Rusia baik yang tergabung 
dalam negara-negara di semenanjung Balkan, Yogoslavia maupun di daerah Uni Soviet lainnya, merupakan salah satu penyebabnya. Di antaranya ada yang berpendapat, bahwa bangunan negara Uni Soviet yang terlalu dipaksakan telah menjadi sumber perenggutan identitas dan krisis federalisme Soviet yang dianggap sebagai akar permasalahannya. Fondasi negara federal Soviet yang berbasis pada masyarakat yang bercorak multinasional, multi-etnis dan multilapis (multilayer), yang selama itu disatukan dengan cara-cara yang represif dan penuh kezaliman, diibaratkan sebagai bangunan rumah kertas yang rapuh, sekali tertiup angin akan runtuh.

Gerakan reformasi, seperti Glasnost (keterbukaan) dan Perestroika (restrukturasi) yang dilancarkan oleh Gorbarchev yang berlangsung sebelumnya, bukannya menjadikan Soviet Rusia dapat utuh-kokoh kembali dan bebas dari krisis ekonomi, melainkan sebaliknya menjadikan negeri Beruang Merah itu lepas kendali, berantakan dan tak mampu dipertahankan lagi (Manuel Castells, 1998). Sekalipun telah banyak analisis atau penjelasan tentang mengapa Uni Soviet runtuh demikian juga mengapa Uni Eropa terbentuk, namun fenomena itu tetap masih merupakan tekateki sejarah. Lebih-lebih kecederungan munculnya fenomena separatisme itu juga merebak di belahan dunia lainnya, termasuk di Indoniesia.

Di Indonesia, tanda-tanda munculnya gejala separatisme paling tidak mencuat sejak akhir 1990-an, yaitu setelah berakhirnya Pemerintahan Orde Baru. Sebagaimana tercermin dalam permasalahan Gerakan Aceh Merdeka (GAM), Gerakan Papua Merdeka, serta isu-isu Riau Merdeka, Republik Maluku Selatan (RMS), serta lepasnya propinsi Timor
Timur menjadj Timor Lorosae. Bagi sejarah Republik Indonesia peristiwa semacam itu boleh dikatakan bukan hal baru. Apabila dirunut lebih jauh ke masa belakang, peristiwa semacam itu sesungguhnya telah banyak terjadi. Semenjak masa Republik Muda, yaitu masa Revolusi (1945-1949) dan masa pasca-Revolusi, yaitu pada tahun 1950-an.

Pada masa-masa itu telah terjadi peristiwa-peristiwa pergolakan politik yang berkecenderungan untuk menentang atau memisahkan diri dari bangunan negara Republik Indonesia yang telah diproklamasikan pada tanggal 17 Agustus 1945. Beberapa di antaranya misalnya, peristiwa pembentukan Negara Pașundàn, Negara Sumatra Timur, dan Negara Indonesia Timur, yang terbentuk atas rekayasa Van Mook setelah perundingan Renville, juga peristiwa Pemberontakan PKI Madiun pada 1948. Peristiwa-peristiwa itu pada dasarnya dapat dikategorikan sebagai gerakan separatisme terhadap Republik Indonesia. Demikian juga, Peristiwa Pemberontakan DI (Daru: Islam) dan TII (Tentara Islam Indonesia) di Jawa Barat dan Aceh, PRRI (Pemerintahan Revolusi Republik Indonesia) di Sumatera, Permesta (Perjuangan Semesta), dan Gerakan Kahar Muzakar di Sulawesi yang terjadi pada tahun 1950-an, juga merupakan peristiwa pergolakan daerah yang bernada separatis terhadap negara Republik Indonesia. Tidak boleh dilupakan, bahwa pembentukan Republik Indonesia melalui Proklamasi Kemerdekaan pada tanggal 17 Agustus 1945, pada hakekatnya juga merupakan keberhasilan gerakan nasionalisme Indonesia dalam mencapai tujuannya untuk mencapai kemerdekaan dengan melepaskan diri dari segala ikatan penjajahan dan bangunan negara kolonial Hindia Belanda yang 
dimiliki oleh Kerajaan Belanda sejak beberapa abad sebelumnya (M.C. Ricklefs, 2001).

Masa sesudah berakhirnya Perang Dunia II di kawasan Asia Timur dan Asia Tenggara juga telah melahirkan ketegangan dan konflik baru yang mengakibatkan timbulnya gejala yang sama, seperti terpecahnya Semenanjung Korea menjadi dua negara sejak 1953, yaitu Korea Utara dan Korea Selatan, dan pisahnya Taiwan dari daratan Cina sejak 1947, serta perpecahan Vietnam Utara dan Vienam Selatan yang telah bersatu kembali setelah berakhirnya perang saudara. Demikian juga selanjutnya, peristiwa pemisahan Singapura dari Malaysia pada tahun 1965 yang kemudian berdiri sebagai negara kota yang cukup berhasil di Asia Tenggara. Persoalan yang sejenis juga muncul di kawasan lainnya, seperti kawasan Asia Selatan (India dan negara sekelilingnya), misalnya pemisahan Pakistan dan Banglades dari India menjadi negara merdeka hingga sekarang, pemisahan Kuwait dari Jrak di Asia Barat (negara-negara Arab), dan peristiwa separatisme di kawasan lainnya di negara-negara Afrika (Eric Hobsbawm, 1996).

Uraian berikut ini secara ringkas dimaksudkan untuk mengulas segi-segi yang berkaitan dengan persoalan tentang bagaimana gejala separatisme itu muncul dalam proses sejarah dari masa lampau hingga kini, mengapa gejala itu muncul dan faktor-faktor apakah yang mempengaruhinya.

\section{Separatisme sebagai Gejala Sejarah}

Dari perspektif sejarah, separatisme sesungguhnya telah lama dikenal, terutama semenjak kehidupan masyarakat manusia mengenal pembentukan bangunan komunitas politik yang besar, yaitu dalam bentuk negara atau kerajaan beserta masyarakat pendukungnya. Perspektif sejarah siklis (cyclical) memandang bahwa bangunan komunitas politik besar dalam perjalanan masa panjang sering mengalami gelombang pasang surut dan hukum organisme "lahir-tumbuh-berkembangruntuh" (origin-growth-develop-decline). $\mathrm{Hal}$ ini sejalan dengan pasang surutnya kelahiran dan keruntuhan kekuasaan yang mampu menyatukan dan mengelola komunitas negara dan masyarakat pendukungnya serta peradaban yang dibangunnya. Sebagai contoh, banyak kerajaan besar yang pernah hidup di pusat-pusat peradaban kuno, seperti kerajaan Mesir Kuno di Lembah Sungai Nil, kerajaan Babilonia di Mesopotamia, Emperium Macedonia dan Emperium Romawi Kuno di Mediterania berakhir dengan masa keruntuhan setelah sebelumnya mengalami masa kelahiran, pertumbuhan dan kejayaannya (Rise and Fall) (Carton J.H. Hayes, 1961)

Kerajaan Macedonia, misalnya, berhasil mencapai kejayaannya menjadi emperium besar di bawah Alexander the Great, melalui ekspansi dan invansi ke daerah lain dengan kekuatan militer. Pada sekitar 200 S.M. Kekaisaran Macedonia menguasai wilayah Mediterania sampai ke daerah Asia Barat, seperti Syria, Punesia, Persia, Mesir, dan bahkan sampai daerah tepi barat Sungai Indus. Namun, belum lama Macedonia mencapai kejayaannya, Alexander the Great, yang di Asia Tenggara dan Indonesia dikenal juga sebagai Raja Iskandar Zulkarnaen, meninggal. Sejak itu Kekaisaran Macedonia runtuh, dan bekas wilayah pengaruhnya terpecahbelah, masing-masing wilayah memisahkan diri sebagai kerajaan yang berdiri 
sendiri di bawah para penguasanya yang berasal dari bekas para panglima perang Alexander.

Seperti halnya Macedonia, Republik Romawi pada periode berikutnya berubah menjadi Kekaisaran Romawi Kuno di bawah para kaisar-kaisarnya yang memiliki ambisi untuk membangun emperium besar dengan melakukan invasi dan ekspansi teritorial dengan kekuatan militer. Wilayah Imperium Romawi juga mencakup wilayah Eropa bagian Barat, daerah Mediterania dan Asia Barat, termasuk Mesir, Palestina, Syria, Mesopotamia dan Asia Kecil. Wilayah Kekaisaran dibagi menjadi dua bagian dan masing-masing di bagi menjadi dua sub-bagian yang disebut Perfektur, dan tiap Pertektur dibagi lagi menjadi unit administrasi yang lebih kecil disebut dioses dan provinsi. Birokrasi pemerintahan disusun secara hierarkhis dari pusat sampai ke daerah, sementara para pejabat yang ditugaskan sebagai kepala daerah diangkat dari pusat, dan terdiri dari para bangsawan terkemuka dan para jendral atau panglima perang Kaisar.

Pada sekitar abad ke 2 S.M. Kekaisaran mulaj mengalami kemunduran, dan akhirnya pada sekitar abad ke 3-4 M. Kekaisaran Romawi runtuh. Pada masa itu pula separatisme terjadi. Bekas wilayah emperium satu persatu memisahkan diri menjadi kerajaan-kerajaan yang merdeka. Para bekas jendral atau panglima perang Romawi juga memegang peran penting dalam gerakan separatisme di bekas wilayah Kekaisaran besar di Eropa pada masa kuno (Hayes, 1961; Crane Brinton, 1990).

Separatisme juga banyak dijumpai dalam sejarah kerajaan-kerajaan lama di Indonesia. Mirip dengan Macedonia dan Romawi Kuno, Kerajaan Sriwjjaya (abad ke 7-11 M.) dan Majapahit (abad ke 14-15) juga mengenal proses pasang-surut. Setelah mampu membangun wilayah pengaruh luas di daerah Nusantara, dua kerajaan itu akhirnya runtuh, dan daerah-daerah yang menjadi bawahannya satu-persatu memisahkan diri dari pusat kerajaan dan beridiri sendiri sebagai kerajaan lokal seperti semula. Pada waktu pusat kerajaan Majapahit lemah, penguasa-penguasa kerajaan lokal satu-persatu tidak lagi datang menghadap ke istana pusat untuk menyampaikan upeti. Kerajaan Islam Demak juga berdiri setelah Majapahit merosot, dan dengan bantuan para Wali Demak melakukan pemisahan diri dari pusat (Kenneth R. Hall, 1985; Babad Demak, Naskah Keraton Yogyakarta.)

Selain itu aksi menentang atau pemberontakan terhadap pusat merupakan salah satu modus operandi untuk melakukan separatisme. Aksi semacam ini sering dikenal dengan istilah mbalelo (menentang untuk tidak lagi tunduk kepada pihak penguasa), merupakan salah satu contoh dari sikap separatis di lingkungan masyarakat Jawa pada masa tradisional. Sejarah kerajaan Jawa pada dasarnya banyak dipenuhi dengan konflik dan peristiwa separatisme. Kerajaan Mataram merupakan salah satu contohnya. Pada awalnya kerajaan yang semula dibangun oleh Senapati diKota Gede ini, semula juga memisahkan diri dari ikatan kerajaan Pajang di bawah Sultan Hadiwijaya. Kerajaan ini didirikan tidak sepenuhnya dengan cara konsensus, melainkan dengan kekerasan. Salah satu di antaranya ialah dengan menundukkan pemuka-pemuka lokal dengan kekerasan, seperti yang dialami oleh Kyai Ageng Mangir, seorang pemuka pedesaan di - daerah Bantul Selatan, yang terpaksa terbunuh karena menentang kepada Senapati. Demikian pula Sultan Agung, cucu 
Senapati, waktu naik tahta ia juga harus menundukkan daerah pesisir dan daerah Jawa Timur (Bang Wetan) dengan caracara yang koersif.

Trunajaya dari Madura memberontak terhadap Sunan Amangkurat I, penerus Sultan Agung di istana Mataram, dapat dipandang sebagai contoh reaksi daerah terhadap pusat kekuasaan kerajaan Mataram, karena adanya tindakan represif dan sewenang-wenang yang dilakukan oleh penguasa kerajaan terhadap kawulanya di daerah. Puncak konflik yang membawa akibat terjadinya separatisme terbesar dalam Sejarah Mataram adalah terjadinya peristiwa pemilahan kerajaan (Mataram) Jawa menjadi dua secara abadi yaitu menjadi Kasunanan Surakarta dan Kasultanan Ngayogyakarta. Peristiwa ini terjadi dengan diadakannya penanda tanganan perjanjian di Giyanti pada 1755, antara Sunan Paku Buwana III dan Pangeran Mangkubumi, yang kemudian menjadi Sultan Hamengku Buwana I (M.C. Ricklefs, 1974).

Proses separatisme ternyata masih berlanjut. Pada 1757 didirikan Kadipaten Mangkunegaran sebagai penyelesaian konflik antara Mas Said dan Kasunanan Surakarta. Demikian juga pada sekitar 1813 Kadipaten Paku Alaman berdiri di Yogyakkarta, sebagai bagian darj pengurangan daerah keraton Kesultanan, sebagai akibat terjadinya kericuan di Yogyakarta ketika Inggris akan menundukkan Keraton Yogyakarta, setelah Jawa jatuh ke tangan pemerintah Inggris 1812. (Sartono Kartodirdjo, at al., 1977; M.C. Ricklefs, 2001; 1974; 1993)

Berbeda dengan pandangan sejarah siklis, pandangan sejarah spiral dan linear berbeda dalam melihat gejala separatisme. Pandangan ini lebih melihat gejala separatisme sebagai bagian dinamika dari proses pergulatan kehidupan masyarakat dalam proses menuju ke arah kemajuan (progress) dan keberhasilan (positive) yang berlangsung baik secara berkelanjutan (continuity) maupun perubahan (change). Sekalipun demikian perlu dicatat bahwa gejala separatisme sesungguhnya merupakan gejala sejarah yang kompleks. Banyak faktor yang mempengaruhinya, baik faktor internal maupun eksternal, dan faktor politik, social, ekonomi maupun faktor kultural. Selain itu, faktor latar belakang proses pembentukan komunitas kerajaan atau negara pada dasarnya juga dapat ikut mempengaruhi lahirnya gejala separatisme. Kompleksitas persoalan yang mendasarinya, menyebabkan eksplanasi tentang separatisme menjadi tidak mudah.

Perlu ditambahkan di sini, bahwa proses pembentukan suatu kerajaan atau negara pada hakekatnya dapat dilihat melalui dua perspektif, baik perspektif teori konflik (conflict theory) atau koersi (coercion) maupun teori konsensus (consensus). Melalui perspektif teori konflik dapat diduga bahwa pembentukan kerajaan atau negara yang berawal dengan melalui koersi (coercion) atau pemaksaan dan kekerasan, terutama yang diujudkan dalam bentuk ekspansi dan invasi teritorial dan kekuasaan, akan memiliki potensi konflik bagi timbulnya kecenderungan separatisme pada masa kemudian. Hal ini terjadi terutama apabila dalam proses pembangunan masyarakat dan kerajaannya tidak terdapat proses integrasi yang wajar dan mantap di lingkungan masyarakat pendukungnya. Tidak lain, karena potensi konflik yang ditimbulkan dari proses pembentukan kérajaan secara koersif dapat menjadi sumber konflik yang berkelanjutan, pada satu pihak, dan pada pihak lain akan menimbulkan pembentukan solidaritas serta 
identitas warga kerajaan yang terbatas dan semu. Situasi semacam itu pada hakekatnya kondusif bagi tertanamnya benih separatisme. Namun hal ini tidak berarti bahwa pembentukan kerajaan atau negara melalui proses alami atau konsensus, tidak akan terjadi separatisme. Hal itu tergantung kepada perkembangan situasi dan kondisi dalam proses pembangunan masyarakat dan negara atau kerajaan, yang sesuai dengan landasan konsensus yang telah disepakati sebelumnya. Sekalipun demikian, proses pembentukan negara atau kerajaan yang berlangsung atas dasar kesadaran kerjasama dan persetujuan sukarela serta didasarkan kepada kepentingan bersama, pada dasarnya memiliki landasan kuat untuk membangun solidaritas dan identitas bangsa yang mantap .

Pembentukan kerajaan melalui proses konsensus bisa terjadi selain karena memiliki faktor-faktor sosial, ekonomi, kultural dan politik tertentu, pengembangan menjadi kerajaan itu juga karena adanya dukungan dari bawah atas persetujuan dan kepentingan bersama untuk memperoleh jaminan perlindungan kehidupan yang penuh kedamaian, ketenteraman dan kemakmuran. Pada satu segi kecenderungan proses pembentukan kerajaan secara alami semacam ini dapat dijumpai dalam proses pembentukan kerajaan-kerajaan lokal pada fase awalnya di berbagai tempat di Indonesia. Diduga kerajaan Kutai, Tarumanegara, dan kerajaan tertua lainnya di Indonesia tumbuh melalui cara demikian. Alasan-alasan historis (pengalaman dan kesadaran bersama), sosial (pertumbuhan demografis) kultura! (kesamaan asal-usul atau etnisitas, bahasa, memori kolektif, tradisi budaya dan system kepercayaan atau agama), geografis (lokalitas yang strategis), ekonomis (kepentingan memperoleh jaminan kemakmuran), dan politik (jaminan memperoleh perlindungan keamanan dan ketenteraman kehidupan) sering mendasari proses pembentukan bangunan kerajaan atau negara pada masa awal.

Seperti telah di singgung di atas, ada pula kerajaan-kerajaan atau negara besar yang dibangun sebagai hasil dari proses ekspansi atau perluasan wilayah melalui penaklukan-penaklukan secara kekerasan oleh pusat-pusat politik lokal (kerajaan lokal) terhadap wilayah komunita politik lainnya. Sudah barang tentu alasan-alasan politik (memperluas kekuasaan), ekonomi (memperoleh sumber ekonomi yang lebih besar), territorial (memperoleh wilayah kekuasaan yang lebih luas), sosial (memperoleh kekuatan pendukung yang lebih besar dan kokoh), agama dan budaya (perluasan kepercayaan keagamaan) juga ikut mendasarinya.

Selanjutnya gerakan separatisme dalam Sejarah Eropa juga marak pada masa terjadinya Reformasi keagamaan di Eropa pada sekitar abad ke 16. Sebutan kaum separatis dan pembangkang telah dikenakan kepada kaum penganut Kristen Protestan yang secara terang-terangan memisahkan diri dari kekuasaan Gereja Katholik Romawi (Catholic Roman Church) di Roma yang telah berabad-abad berpengaruh di Eropa. Sebutan itu semula sudah barang tentu datang dari pihak Gereja Romawi. Sementara dari kaum Protestan yang dipimpin oleh Martin Luther, Zwingli dan Calvin, menamakan diri sebagai kaum Pembaharu atau Pemurni (Puritan). Peristiwa pemisahan diri ini mulai terjadi ketika Martin Luther dari Jerman melancarkan protes dan kritik terhadap Gereja Romawi yang dianggap telah menyimpang dari ajaran Kristen yang 
sebenarnya. Protes dan kritik Luther itu dirumuskan dalam sebuah, plakat yang berisi 95 dalil kesalahan dan penyimpangan Gereja Romawi terhadap keaslian ajaran Injil yang sebenarnya pada tahun 1517. Kaum separatis yang radikal itu kemudian mendirikan kongregasi dan memilih pastor-nya sendiri; menyusun aturan sendiri, dan membuat bentuk dan cara ibadahnya sendiri. Termasuk di dalamnya tempatibadahnya, yaitu gereja Protestan. Sebaliknya gerakan separatis- me kaum pengikut Protestan itu pada masa kemudian dijawab oleh. Gereja Katholik Romawi dengan gerakan Reformasitandingan (Counter-Reformation), dengan melakukan pembersihan dan-reorganisasi ke dalam secara ketat. Gerakan separatisme Protestan pada masa kemudian memperoleh dukungan dari kaum 'nasionalis di Eropa yang sedang berusaha mendirikan negara atau kerajaan-kerajaan nasional dengan memisahkan dịi dari wilayah emporium kerajaan besar, dengan mengklim memerdekakan diri dan mendirikan kerajaan sendiri berdasarkan identitas bangsa sendiri berupa pemilikan kesatuan bahasa dan tradisi budaya yang dimilikinya. Agama Kristen Protestan menjadi lengkap untuk menjadi simbol separatisme politik dari kesatuan kerajaankerajaan besar pada masa itu (Hayes, 1961; Brinton, 1990).

\section{Separatisme sebagai bagian dari Gerakan Nasionalisme dan Glóbálisasi}

Sejak awal kelahirannya. Nasionalisme telah menjądi faktor pendorong bagi pertumbuhan kesadaran bangsa (nation) dan negara bangsa (nation-state) serta penggerak gerakan separatisme untuk mendirikan negara baru dengan memisah- kan diri dari, ikatan negara sebelumnya. Proses dekolonisasi yang diikuti dengan kelahiran sejumlah besar negara merdeka dari bekas negara jajahan yang terjadi di berbagai belahan dunia pada masa pasca Perang Dunia II, pada umumnya dipicu oleh kelahiran semangat nasionalisme yang tumbuh di wilayah tersebut.

Seperti telah di singgung di atas di tempat asal kelahirannya, yaitu Eropa, paham nasionalisme juga menjadi faktor pendorong bagi terbentuknya negara-negara kerajaan nasional di Eropa pada abad 17 - 18. Selain faktor ethno-linguistik (ethnisitas dan kesamaan bahasa), dan kesamaan memori sejarah, maka kesamaan agama pada waktu itu ikut dijadikan sebagai dasar untuk membangun konsep nasion bagi sementara masyarakat Eropa yang hidup di bawah empirum atau kerajakerajaan besar yang terbentuk pada masa Abad Pertengahan. Maka dapat dipahami bahwa kelahiran Protestantisme dalam Era Reformasi pada masa itu disambut oleh kelahiran negara-negara kerajaan nasional baru yang ingin bebas dari ikatan negara Monarchi yang besar sebelumnya. Oleh karena itu Protestantisme mendapat sambutan besar di Jerman, di daerah Eropa Timur ( Batkan dan Slavia), Eropa Utara, dan Eropa Barat termasuk Belanda dan berperan penting sebagai simbol perlawanan terhadap negara-negara lama yang kebetulan bernaung di bawah payung Gereja Katholik Roma. Demikian pula Kerajaan Inggris menggunakan simbol agama untuk memperkuat alasannya untuk menolak segala pengaruh politik dari negara-negara di Kontinen. (Eropa) melalui pemisahkan diri dalam bidang keagamaan dari ikatan Gereja Katholik Roma dengan cara mendirikan Gereja "Nasional" ala British, yaitu Gereja (Protestan) Anglikan yang menem- 
patkan Sang Raja sebagai pemimpinannya bukan Paus.

Revolusi Perancis (1789) pada dasarnya menjadi sumber penyebaran semangat nasionalisme tidak hanya di Eropa tetapi juga ke wilayah luar Eropa yaitu Asia dan Afrika terutama pada awal abad ke-20. Slogan Revolusi Perancis terkenal "liberty, eglity, fraternity" (kebebasan, persamaan dan persaudaran) menyebar luas dan mendasari kelahiran semangat nasionalisme di tempat lain dan mendorong kesadaran dan kebangkitan untuk membangun bangsa dan negara yang merdeka, yang didasarkan atas persamaan, keadilan, dan persaudaraan. Di negara-negara jajahan, termàsuk di Indonesia pada masa kolonial, nasionalisme menjadi simbol kebangkitan kesadaran kebangsaan baru, dengan ciri khasnya anti kolonialisme-imperialisme, absulutisme, dektaktorisme, feodalisme, dan fasisme. Konsepsi pembentukan nasion atau bangsa dan negara bangsa kebanyakan didasari oleh prinsip-prinsip persamaan ethnisitas, bahasa, agama, wilayah (territorial), dan pengalaman dan memori sejarah, yang semenjak abad ke-19 berkembang di Eropa, menjadi landasan penting bagi nasionalisme yang berkembang di dunia luar Eropa (E.J. Hobsbawm, 1990).

Dalam perkembangannya kosep nasionalisme pada dasarnya menjadi sangat ambigu. Pada satu pihak, nasionalisme diartikan sebagai faktor pebangkit proses pembangunan bangsa, yaitu berkaitan dengan pendirian negara dan pembangunan bangsa dan negara. Akan tetapi, pada pihak lain, nasionalsime dapat dikaitkan dengan pemberontakan dari suatu kelompok yang berada di daerah pinggiran wilayah negara terhadap negara nasional yang membutuhkan integrasi nasional, seperti yang terjadi pada periode akhir abad ke-20 ini. Nasionalisme semacam ini juga beriaku dengan gerakan pemberontakan atau penentangan terhadap kekuatan-kekuatan hegemonial dari tatanan dunia global baik dalam politik, ekonomi maupun kultural yang berkecenderungan menghomoginisasi kebudayaan dunia. Konsep bangsa, dengan demikian juga menjadi rumit, misalnya, bangsa dianggap sebagai "imagined" and "invented" communities, dan identitas nasional yang dibentuk dengan cara memisahkan diri identitas dan kepercayaan dari kelompok lain yang berbeda. Oleh karena timbul benturan (clash) dengan nasionalisme yang tidak toleran (intolerant) dan tidak suka berdamai (irriconsible) yang pada hakekatnya menjadi sumber masalah di dunia pada abad ke-20. Banyak bentrokan-bentrokan atau konflik ini terjadi di Eropa, terutama bagian tengah dan timur. Sementara di tempat lain masih terdapat permasalahan yang cukup rumit untuk dipecashkan secara tuntas, seseperti permasalahan pertentangan antara Israel dan Palestina, serta pertentangan di negara-negara Timur Tengah, serta masalah Suku Kurdi di Turki dan Irak, dan Suku Tamil di Asia Selatan, dan tidak kurang rumitnya persoalan Irlandian dan Inggris.

Di pihak lainnya lagi, nasionalisme di Eropa pada abad ke-19 bukan saja menjadi faktor pendorong pembangunan bangsa; tetapi pada masa kemudian justru menjadi sumber penggerak lahirnya semangāt kolonialisme dan imperialisme Eropa. Semangat nasionalisme yang berlebihan atau ultra nasionalisme mendorong gerakan ekspansi dan invasi dengan kekerasan ke wilayah luar Eropa, dengan semboyan untuk kejayaan negara dan bangsa, untuk kemakmuran negerinya, dan dengan 
dalih untuk mengadabkan bangsa lain karena mereka merasa sebagai bangsa yang paling beradab. Tidak heran apabila semboyan "Gold, Glory and Gosper" dari semenjak ekspansi Portugis ke luar Eropa sampai dengan kolonialsiome-imperialisme Eropa pada abad ke 19 di Asia dan Afrika pada masa kemudian masih bergaung sekalipun dalam bentuk yang lain, sebagaiman tercermin dalam masa Perang Dingin dan Pasca Perang Dingin pada akhir abad ke-20 dan awal abad ke 21 ini. Secara implisit semangat itu pada dasarnya masih menjelma dalam semangat ekspansi kapitalisme global pada masa kini. Inkarnasi semangat nasionlisme yang berlebihan itu pada hakekatnya juga tampak dalam diri politik luar negeri negara Adi Kuasa Amerika Serikat bersama dengan kelompoknya pada masa Pasca Perang Dingin ini. Bukankah itu merupakan bentuk baru dari jenis Nasionalisme "Pongah" di abad ke21 ?

Akhirnya patut dicatat bahwa pemulihan suasana krisis multidimensi seperti yang dialami lndonesia dan negara berkembang lainnya pada masa kini tampaknya belum memiliki titik terang, mengingat stabilitas politik dan ekonomi global masih.terganggu dan terancam goncang, sementara kondisi internal belum stabil dan bahkan cenderung ricuh, maka dapat diduga suasana kehidupan yang penuh kedamaian dan ketenteram bebas dari konflik, ketegangan serta ancaman perpecahan masih jauh dari harapan. Hal ini berarti bahwa perkembangan dunia pada awal abad ke-21 belum memberikan harapan kehidupan masa datang yang lebih cerah dan pasti bagi masyarakat dunia dan juga masyarakat dan bangsa Indonesia. Globalisasi tampaknya masih dipandang sebagai momok (mengkhawa- tirkan) dari pada menjadi idaman atau harapan bagi kemajuan dan kemakmuran negara-negara berkembang, mengingat tuntutan persaingan yang dibawa globalisasi pada hakekatnya tidak akan menguntungkan negara berkembang (miskin) dan sebaliknya hanya akan memperkuat negara maju.

\section{Penutup}

Uraian singkat di atas mengemukakan bahwa pada dasarnya separatisme merupakan gejala sejarah, yang telah muncul dalam perjalanan kehidupan sejarah masyarakat manusia dari masa lampau hingga kini.-Sebab timbulnya separatisme berkaitan erat dengan berbagai faktor baik politik, ekonomi, sosial maupun kultural, bahkan juga keagamaan dan ideologi yang ada pada lingkungan masyarakat atau golongan pendukung gerakan tersebut. Separatisme telah terjadi pada masa kerajaan Mesir Kuno maupun kerajaan di Mesopotamia, maupun pada masa peradaban Yunani dan Romawi Kuno mencapai puncaknya. Demikian juga separatisme merupakan bagian dinamis dalam masa Reformasi, Pencerahan, Revolusi Perancis, dan juga ikut menjadi unsur kelahiran nasionalisme di Eropa, dan di Asia, Asia Tenggara, termasuk Indonesia.

Separatisme juga merupakan gejala sejarah yang telah lama dikenal dalam dinamika sejarah kerajaan-kerajaan di Nusantara, termasuk di Jawa. Konflik dan perpecahan dalam lingkungan kerajaan Jawa telah terjadi sejak keruntuhan Kerajaan Majapahit, Demak, Pajang sampai dengan kerajaan Mataram. Namun kecenderungan semacam itu kadang-kadang masih muncul pada masa kini, tentu perlu dipandang sebagai bagian dinamik dan 
Topik : Separatisme dalam Perspektif Sejarah, Djoko'Suryo .

tantangan bangsa yang perlu dipecahkan dengan pendekatan yang sesuai dengan tuntutan kehidupan masyarakat bangsa yang modern yang berbeda dengan masyarakat Indonesia pada masa tradisional. Separatisme pada hakekatnya bisa ditanggulangi antara lain derigan pengembangan semangat kebangsaan baru yang perlu lebih menekankan prinsipprinsip, kemanusiaan, pendidikan, demokrasi, kebersamaan, keadilan, persamáan, kesetaraan, serta persaudaraan dan semangat ke-Indonesia-an yang seluas-luasnya. Dengan tekad bersama yang'kuat dan kokoh dalam diri semua anggota masyarakat Indonesia untuk mempertahankan keutuhan bangsa dan negarầlndonesia. Insyaallah kecenderurigan' municulnya gerakan separatisme di Indonésia-dapat ditanggulangi dengan baik.

\section{Daftar Pustaka}

Babad Demak, Naśkah, Kérátọn Yogyakarta.

Brinton, Crane. 1990. A History of Western Moral.New York: Paragon House.

Castells, Manuel. 1998. End of Millenium. The Irformation Age: Ecoñomy, Society and Culture. Vol.III. Oxford: Blackwell Publishers.
Hall, Kenneth'R., 1985. Maritime Trade and Development in Early Southeast. Asia.Honolulu: University of Hawaii Press.

Hayes, Carlton J.H', et al., '1961. History of Europe. New' Y'ork: The Macmillan Company:

Hobsbawm, E.J., 1995. Nations and Na- . tionalism Since 1780. Programme... . Myth, Reality. Cambridge: Cambridge University Press. $\therefore$ 1996. The Age of Extremes. A His-

$\therefore$ tory of World, 1914-1991. New York: 'Vintage Books.

Pointing, 'clive, 1999. The Twentieth Century. A, World History. New York: A John Macrae Books.

Ricklefs, M.C., '1974. Jogjakarta under Sultan Mangkubumi, 1.749-1792. A His- . tory of the Division of Java. London, etc.: Oxford University Press.

Ricklefs, M.C. `1993. War, Culturé and "Económy in Javà, 1677-1726. Asian and European 'Imperialism in the 'Earily Kartasüra 'Period.Sydney: 1, 'ÁÄlen '\& Únwin. 2001. A History, of Modern Indonesia, Since c. 1200. Houndmills, etc.: Pagrave.

Sartono Kartodirdjo; at al:', 4977. Sejarah. Nasional Indonesia. 6 Jilid. Jakarta; Balàj Pustaka. 